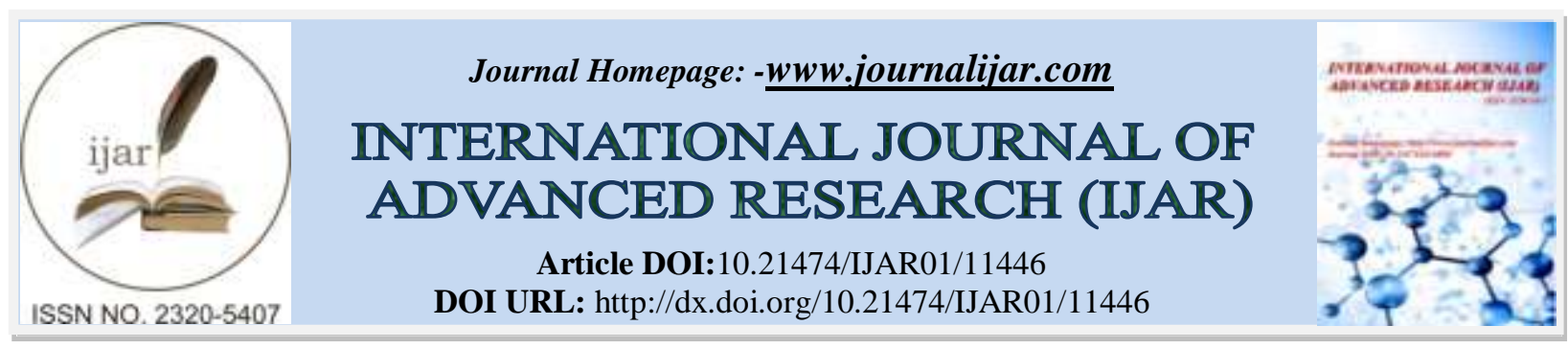

RESEARCH ARTICLE

\title{
DETERMINANTS OF CORPORATE INVOLVEMENT IN SOCIAL IMPACT
}

\author{
Dr. Manjula Gujjar \\ Faculty, Business Studies, Post Graduates Saskatchewan Polytechnic.
}

\section{Manuscript Info}

Manuscript History

Received: 31 May 2020

Final Accepted: 30 June 2020

Published: July 2020

Key words:-

CSR, SME, Social Impact, Ethics, Profit

\begin{abstract}
An appropriate balance between corporate and community interests would help meet the needs and expectations of business owners and their stakeholders. This could be achieved through their involvement in Corporate Social responsibility (CSR) initiatives.This study attempts to answer the question posed by BBB (Better Business Bureau)to Saskpolytechnic relating to the involvement of businesses in CSR initiatives. Hence, research is conducted to identify the determinants of CSR initiatives of businesses. This researchconducts desk research and adopts a multivariable regression model to find determinants of CSR initiatives. It uses the concepts of legitimacy theory to understand organizational legitimation and the Agency theory to identify factors influencing corporate stewards to be proactive towards community service. It further explores the environment in which businesses operate and their willingness to engage in CSR activities and disclosure of CSR information.
\end{abstract}

Copy Right, IJAR, 2020,. All rights reserved.

\section{Introduction:-}

The policy of Corporate Social Responsibility (CSR), has come to be implemented in many developed as well as developing countries. This public policy has been conceived as a balancing act of hidden contradictions in government policy towards the corporate sector. CSR is intended to encourage the corporate enterprises to spend some appreciable amounts of their net profits on broader social and economic projects like in health, education and urban environment intended to benefit the wider community. This seemingly laudable public policy is also expected to soften and perhaps silence the public criticism of the tax bonanza handed out to the corporate sector to encourage investment and create employment. If the corporate enterprises which have come to pay corporate tax of about 25 percent as compared to 30 to 35 percent of personal income tax, spend some portion of their net profit on projects which go to benefit the broader community, the government will be in a stronger position to defend the low tax bonanza given for the corporate sector.

But in many countries, all corporate enterprises do not spend any appreciable amounts on CSR projects. This is true of Canada also. No doubt some corporate enterprises do spend some amounts but not to the required extent of two to three percent of the net profits. Besides, some corporate enterprises not only spend the required amount on socially beneficial projects but also engage in making donations to community organizations like hospitals, universities and museums. In other words, we see clear variations in the behavior of different corporate enterprises in their decision to spend on CSR projects. What are the reasons for such variations in corporate decision making? Is it because such spending will reduce their profits? If so, it proves the long-established belief that private corporate enterprises are guided by the motive of earning more and more profits for their shareholders. All other explanations presented by 
way of theories of corporate motives fall to the ground. This becomes evident if we analyze the evolution of corporate enterprise briefly as a unit of modern capitalism. Hence, the author has presented the evolution of corporate enterprise in the process of the development of modern capitalism in the next section.

\section{Evolution of Modern Corporate Enterprise:}

The Jewish Merchants of the city of Venice in Italy laid the foundation for modern capitalism, (Gleeson-White JL, 2011). They devised modern banking methods and financial instruments for transferring money without using legal tender cash. Then they developed the double-entry accounting method, which enabled the merchants to correctly record income and expenditure and costs and profits from their trading activities. These developments laid the foundation for modern capitalist enterprises, (Rabie, M. ,2013). The idea of investing in earning profits evolved into forming companies and the governments of the day started giving legal status to such companies by registering them on payment of fees. That was how the East India Company was registered and incorporated in England with the approval of the British government.

The evolution from trading to production activity started with engaging the artisan workers to produce products in demand. And the merchants supplied raw materials required to produce the intended products to the artisan workers at their homes. Those artisans used the raw materials to produce the products whose designs were given by the merchants. At that momentous period, a wind of change started blowing all over Europe. Europe experienced a renaissance in learning, thinking, art, music painting and science. The development of science gave rise to technological development and technological development resulted in the invention of the steam engine. After these developments, the merchants started asking the workers to leave their homes and come and work at a commonplace called factory where they were supplied with raw materials and supervised their work. This came to be known as the factory system. This factory system resulted in largescale production of goods requiring a huge market for their absorption. This requirement resulted in merchants taking up sea voyages in search of new markets. They solicited the involvement of Kings and Queens in the colonial expansion of markets for their products. Those companies which were given legal status gradually issued shares to the public to raise huge capital required for their international trade. That was how those limited liability companies got transformed into present-day corporate enterprises. When this corporate transformation evolved, many social and economic consequences emerged which were not always to the benefit of workers employed and even to the society at large. These adverse social and economic consequences resulting from the working of corporate enterprises attracted the attention of the intelligentsia like Charles Dickens and Karl Marx. They exposed the exploitation of workers by the owners of factories which degenerated to human degradation and the creation of wide economic inequalities. These adverse social and economic consequences of the working of corporate enterprises were debated in many fora and the governments of the day were compelled to introduce laws to regulate the working conditions, payment of wages and payment of other welfare benefits to the workers. Besides, the governments also started levying taxes on the profits of the corporate enterprises to mobilize government revenue for the general purpose of the governments. When the level of corporate taxes started going up, corporate enterprises started creating political lobbies to influence the governments to reduce corporate taxes. These lobbies also employed experts to argue for the reduction of the level of corporate taxes.

Another phase of modern capitalism emerged in the past two decades. Because of fast technological changes, modern corporations had to hire highly trained workers. But the cost of high skilled workers skyrocketed in many developed countries. They started facing a high cost of labor where high minimum wages were enforced and where a declining working population created labor scarcity. This situation compelled modern corporations to shift their production activities to other low wage cost countries to reduce wage costs. The modern corporations are interested in reducing costs and increasing profits for their shareholders. Their decisions are guided by the ways and means of reducing the product cost which will make it cheap to attract customers. This will increase their profits. Corporate social responsibility has come to be imposed on modern corporations because, in addition to paying lower taxes, they use publicly built physical, social and economic infrastructure facilities. Therefore, the idea of encouraging corporate enterprises to agree to spend a portion of their net profits on social sector projects for the benefit of the wider public has been justified and the corporate sector has also accepted it. But its implementation has not been encouraging as all the corporate entities do not voluntarily spend on social projects which benefit the wider community. This variation raises doubt about the rationale of the tax incentives by way of lower taxes on corporate enterprises. Instead, is it not desirable to tax them on par with individuals and use the revenue for spending on social sector projects? Before making such a suggestion, it would be desirable and also in keeping with a democratic tradition, to make further study of the issues involved. Accordingly, an attempt is made in this paper to study the 
behavior of corporate enterprises in Canada in regard to their spending on social responsibility projects which are expected to benefit the wider public. Besides, an attempt is also made to investigate whether corporate spending on CSR projects adversely affects their profitability.

\section{Conceptual Clarification:}

This research has used the concept of corporate social responsibility as a broader social obligation not legally binding but an expression of moral conduct. The expression is expected in the form of spending a portion of corporate profits on projects which the public at large considers as socially beneficial to the wider community. Such projects are broadly indicated in the legislation.

Corporate social responsibility does not include public grants and donations by corporate enterprises to private hospitals, private educational institutions and museums. CSR also does not include direct or indirect advertisements and on political canvassing.

Carroll's Pyramid of Corporate Social Responsibility (CSR) conceptualizes corporate social responsibility (CSR) in the form of a pyramid, having four layers, and each layer indicating the type of responsibility that must be considered while businesses engage in CSR initiatives (Carroll, 2016). The responsibilities being: economic, legal, ethical and philanthropic. This study approaches CSR as a whole, incorporating all types of responsibility in line with Carroll's Pyramid in an attempt to answer our research question. This study evaluates Companies based on what makes them involve in CSR activities.

\section{Research Question:}

The research question posed by Better Business Bureau (BBB) formulates:

What will help business want to be involved in social impact?

This research question focuses on a business phenomenon.

\section{Literature Review:-}

Corporate social responsibility is voluntary in nature and is an indicator of ethical behavior by businesses. Unethical corporate behaviors lead to corporate collapse.

There is increased pressure on corporations to be responsible. Several theories support the view that ethical behavior is necessary for businesses to survive and grow. One such theory called the "Legitimacy theory" helps organizations understand the essence of ethical behavior and suggests voluntary CSR disclosures as part of the process of organizational legitimation (Van der Laan, 2009). Besides, Legitimacy theory is one of the popularly adopted theories by businesses and it explains the phenomenon of corporate social disclosures through useful insights (Mousa et al., 2015). John Dowling and Jeffery Pfeffer (Dowling and Pfeffer, 1975), in their works on Organizational legitimacy, highlight that Organizations seeks to establish congruence between social values adopted by businesses through CSR initiatives and norms of acceptable behavior in the social system. When there is the disparity between these two values, i.e. Social values and norms of acceptable behavior in the society, there exists a threat to organizational legitimacy. Hence it is important for organizations to involve in CSR activities and engage in voluntary disclosures.

Since CSR is a voluntary move by corporations, and there is no legal binding imposed on their decision to involve or disclose CSR activities, many firms do not fully engage in such activities. Hence, managers of companies are not under compulsion to be proactive in CSR initiatives. But there is societal pressure on corporations acting which can be considered as a driving force to engage firms to involve in social activities. Past studies have found that firms with well-implemented CSR initiatives excel their competitors significantly, on average. But this is true only when the CSR initiatives are well-executed in order for the firm to have a competitive financial advantage (Jackson and Hua, 2009).

Hence, CSR initiatives should be effectuated in a manner that transfuses corporations and girdles all business processes. These business processes must majorly include management processes such as corporate governance and strategic planning. The level of CSR activities undertaken by SMEs often depends on the decisions of their managers and the value orientation of the entrepreneur (Badulescu et al., 2018). Stewardship theory introduced by (Donaldson and Dams 1989) highlights that managers tend to become proactive and tend to involve in CSR activities if they are given independence to act on their own. The theory accentuates that managers acting as agents 
behave in a community-focused manner directing moral behavior towards the firms and shareholders when left on their own (Subramanian, 2018).

Sustainability is a critical factor for businesses today. Hence it is vital for businesses to adopt strategies and activities that help active its business objectives and earn the community's goodwill. Being a socially responsible company can undergird a company's image and enhance its social visibility. The extent to which a company is known to the public constitutes its social visibility. Past studies have found a positive influence of social visibility on the firm's CSR activities (Gamerschlag, Möller and Verbeeten, 2011; Schreck and Raithel, 2015). Most studies have adopted the method to measure the social visibility of firms as per GRI (Bertazzi, n.d.; Wilburn and Wilburn, 2013). This study adopts a similar methodology and explores the relationship between CSR activities and social visibility in the context of Saskatchewan.

Some of the past studies have adopted financial metrics as a measure of social visibility since companies listed on the Dow Jones sustainability world Index (DJSWI) are perceived as world leaders. A study conducted by (Rodolphe Darand and colleagues, July 2019) found that DJWSI listing did not help boost firms' stock prices or trading volume. This can be perceived as more than being visible. For financial performance, a firm's visibility for social causes enhances its image and reputation. Past studies conducted by researchers John Kuang, Wei Jiang and Dam Vitalis support this claim (2019, Network for business sustainability). In order to explore the stated findings, this study conducted regression analysis of 50 listed companies in Canada with CSR as dependent variable and company reputation along with other financial metrics such as profitability and leverage as independent variables. The model was found to be insignificant. Further, this study went on to explore by considering only one independent variable, i.e. company and found the model to be insignificant, proving that company reputation did not impact its CSR involvement in the context of the organizations in Canada considered in this study.

Also, the past studies conducted have found the age of firm influencing the firm's involvement in CSR initiatives, and research has proved that long-established firms seem to involve voluntarily in social impact and social disclosures (Roberts, 1992; Hossain, 2008; Alturki, 2014), based on these findings, this study also explores this claim by including the age of the firm as one of the independent variables in its regression model.

Organizations make efforts to find an equilibrium between economic, social, environmental and legal requirements in order to yield returns to the stakeholders and the community (Badulescu et al., 2018). One of the research studies has brought to light the fact that a firm's socially responsible policies transform into higher profits and higher profits transform into socially responsible policies (Mercedes Rodriguez-Fernandez, 2015). Hence more and more firms are influenced to behave ethically and also be socially involved. It is not enough for firms to only focus on generating profit returns to shareholders but should consider being responsible towards its stakeholders such as customers, employees, community and society at large.

Past studies by some researchers have revealed that a firm's profitability has a positive relationship with respect to CSR activities. But yet the relationship between CSR and companies' profitability expressed as financial performance has been inconclusive, controversial and needs further exploration since some studies found negative and some neutral relationship between corporate social responsibility and financial performance (Alexander \& Buchholz,1978; Abbott \& Monsen, 1979). Thus, the consensus has not been reached on the relationship between CSR and profitability (Marom, I. Y. (2006), (McWilliams, A.\& Siegel, D. 2001), hence this research explores the relationship between CSR and a firm's profitability in the context of Saskatchewan to fill the gap.

The common metrics used for measuring CSR activities are content analysis (Thomas, 2014; Akin \& Yilmaz, 2016; Horúcková and Baudassé, 2017). But some studies have adopted the CSR costs as a metric to measure a firm's spending on CSR activity (Zakari, 2017). This study adopts CSR ranking score published by CSRHub as a metric to measure CSR activities of firms in Canada, majorly headquartered in Saskatchewan.

Several researchers have reported that the Firm's size is positively related to its CSR initiatives (Dierkes\& Preston, 1977; Patten, 1991; Roberts, 1992; Hackston\& Milne, 1996; Adams et al., 1998; Kansal et al.,2014; Waluyo, 2017). Meaning the larger the size of the firm, the more is their involvement in social activities. This claim can be justified by the fact that larger firms have more social visibility and remain in the scanner of the public and in order for them to earn the goodwill of the public, it is important for them to present themselves as a responsible company and appear empathetic towards the less fortunate. This enhances their image and also the customer population. 
Also, big companies are more high profile and attract media attention and, in a bid, to protect and intensify their reputation with the public and stakeholders, they engage actively in CSR initiatives (Smith, 2013). Hence this study explores the relationship between size and CSR in the context of Canada. Most of the past studies have considered large companies for exploring the firm's involvement in SR activity, not much research has been done to explore the involvement of small and medium-sized enterprises in CSR initiatives. Hence this research considers SME's involvement in CSR initiatives to cover the existing gap involving SMEs' involvement in social impact.

Besides, involvement in community causes attracts more shareholders and also in the process they can function legitimately and avoid government scrutiny (Purushotahman et al., 2000), hence it is important for companies to involve in community activities.

\section{Empirical Analysis:}

Since firm characteristics are very important determinants of CSR practices (Gamerschlag et al., 2011), hence the impact of some firm-specific factors such as profitability (ROI), leverage, firm size and firm's age influencing the firm's involvement in CSR activities will be examined.

\section{Sample and data size:}

The main purpose of this study is to explore the factors influencing a company's involvement in CSR activities in the context of Canada. To achieve this objective this study collected majority of the financial data from the annual reports of the listed companies in Canada and from macrotrends, a research platform which provides 100 plus years of economic data of all major companies in the world. The data for CSR ranking score is obtained from CSRHub, which provides access to corporate social responsibility and sustainability ratings information on 17,268+ companies from 134 industries in 143 countries.

This study adopts multivariate regression analysis on cross sectional data for the year 2019. The CSR ranking is the dependent variable and independent variables include firm age, firm size, leverage and profitability (ROI is used as a proxy for profitability). In the first part of empirical analysis, this study focuses on companies headquartered in Saskatchewan. Out of 55 companies headquartered in SK, only 37 companies have CSR ranking scores and the rest have not been rated and hence no data is available, limiting the sample size to 37 .

In the second part of the empirical analysis, listed companies from other provinces in Canada for whom the CSR ranking scores are available are added thus increasing the sample size to 90 and regression analysis is conducted. Since data sets for 2 different regions within the country are studied, this research helps to identify, how geographical location impacts a firm's involvement in CSR activities apart from the influence of financial metrics considered in the study.

\section{Regression Analysis:}

\section{Regression analysis is used to:}

1. Predict the value of a dependent variable based on the value of at least one independent variable

2. Explain the impact of changes in an independent variable on the dependent variable

Dependent variable: Is the variable we wish to predict or explain

Independent variable: the variable used to explain the dependent variable

In our dataset- Corporate Social Responsibility $=$ Dependent Variable

Firm age, firm size, Profitability, and leverage of the firm are Independent variables.

The multiple linear regression model equation is:

$$
Y_{i}=\beta_{0}+\beta_{1} X_{1 i}+\beta_{2} X_{2 i}+\cdots+\beta_{k} X_{k i}+\varepsilon_{i}
$$

Here $\mathrm{Y}=\mathrm{CSR}$ ranking score of listed companies in Canada $=$ Dependent variable

$\beta_{0}=\mathrm{Y}$-intercept

$\beta_{1}=\beta_{2}=\beta_{3}=$ Population slopes

$\varepsilon_{\mathrm{i}}=$ Random Error

$\mathrm{X}_{1}=$ Firm Age 
$\mathrm{X}_{2}=$ Firm Size

$\mathrm{X}_{3}=$ Firm's Profitability

$\mathrm{X}_{4}=$ Firm's Leverage

So the Regression Equation can be written as:

$$
\widehat{Y}_{i}=b_{0}+b_{1} X_{1 i}+b_{2} X_{2 i}+\cdots+b_{k} X_{k i}
$$

Where $Y_{i}$ is the Estimated or predicted value of $Y ; b_{0}=$ estimated intercept

$\mathrm{b}_{1}, \mathrm{~b}_{2} \ldots \mathrm{b}_{\mathrm{k}}$ are the estimated slope co-efficients.

\section{Part 1: Saskatchewan Companies:}

Thirty-seven Saskatchewan Companies are used in this study.

\section{Co-efficient of multiple determinations:}

The R-squared of the regression is the fraction of the variation of the dependent variable that is accounted for (or predicted by) the independent variables.

$\mathrm{R}^{2}$ reports the proportion of total variation in $\mathrm{Y}(\mathrm{CSR})$ explained by all X (Firm size and Profitability) variables taken together.

$\mathbf{r}^{2}=0.3342=0.33$

Table 1-1:- Regression Statistics.

\begin{tabular}{|l|l|}
\hline \multicolumn{2}{|l|}{ Regression Statistics } \\
\hline Multiple R & 0.57810371 \\
\hline R Square & 0.3342039 \\
\hline Adjusted R Square & 0.29503942 \\
\hline Standard Error & 19.0344575 \\
\hline Observations & 37 \\
\hline
\end{tabular}

From our regression statistics generated by Excel: $\mathbf{R}^{\mathbf{2}}=\mathbf{0 . 3 3 4}$

So, we can infer that $33 \%$ of the variation in CSR score is explained by the variations in the firm size and profitability.

Adjusted $\mathrm{r}^{2}=0.29=0.3$

taking into account the sample size (37) and number of independent variables (2).

Now we have to check if the Model is significant

To check we conduct the F-test:

1. F Test is conducted for checking the Overall Significance of the Model

2. F-test Shows if there is a linear relationship between all of the $\mathrm{X}$ variables considered together and $\mathrm{Y}$

\section{Hypotheses:}

$\mathrm{H}_{0}: \beta_{1}=\beta_{2}=\beta_{3}=0$ (No linear relationship).

$\mathrm{H}_{1}$ : at least one $\beta \mathrm{i} \neq 0$ (at least one independent variable affects CSR scores for companies)

F-test for overall significance:

Table 1-2:- Anova Analysis Results.

\begin{tabular}{|l|l|l|l|l|l|}
\hline ANOVA & df & SS & MS & F & Significance F \\
\hline & 2 & 6183.44 & 3091.72 & 8.533343 & 0.000992662 \\
\hline Regression & 34 & 12318.56 & 362.3106 & & \\
\hline Residual & 36 & 18502 & & & \\
\hline Total & & & & & \\
\hline
\end{tabular}

$\mathrm{df}_{1}=2, \mathrm{df}_{2}=34 \mathrm{~F}_{\alpha}=3.27$ from the table for $\alpha=0.05$ (for $95 \%$ confidence interval)

From our calculations, $F$ value is 3.27 and from our analysis report $F$ value is 8.53 which is $>F_{\alpha}=2.37$; so, it lies in the rejection region, so we reject the null hypotheses.

The p value tells us how confident we can be that each individual variable has some correlation with the dependent 
variable, which is the important thing.

So, considering the $\mathrm{P}$-value, at $\alpha=0.05$ ( $\mathrm{p}$-value $<.05$ ), reject $\mathrm{H}_{0}$

Since the $\mathrm{p}<.05$, accept the alternate hypothesis, i.e. at least one independent variable affects the CSR score.

\section{Conclusion:-}

There is evidence that at least one independent variable (profitability, firm size) affects the CSR scores of companies. So, the Model is over all significant.

\section{To check if individual variables are significant: T-Test:}

We conduct the T-test to check if each of the independent variables (i.e. Firm age, Firm Size, Profitability and Leverage) are significant individually are not.

1. Use $t$ tests of individual variable slopes

2. Shows if there is a linear relationship between the variable $\mathrm{X}_{\mathrm{j}}$ and $\mathrm{Y}$.

The t statistic is the coefficient divided by its standard error. The standard error is an estimate of the standard deviation of the coefficient, the amount it varies across cases. It can be thought of as a measure of the precision with which the regression coefficient is measured.

In simple or multiple linear regression, the size of the coefficient for each independent variable gives us the size of the effect that variable is having on our dependent variable, and the sign on the coefficient (positive or negative) gives us the direction of the effect. In our test case, all the coefficientsarepositive.

Table 1-3:- T-Test results.

\begin{tabular}{|l|l|l|l|l|}
\hline & Coefficients & Standard Error & t stat & p-value \\
\hline Intercept & 7.632907 & 19.3218001 & 0.395041 & 0.695280055 \\
\hline Company size & 16.05895 & 4.860734454 & 3.303812 & 0.002252885 \\
\hline Profitability & 0.234784 & 0.478100718 & 0.491077 & 0.62652678 \\
\hline
\end{tabular}

Test Statistic

$(\mathrm{df}=\mathrm{n}-\mathrm{k}-1)=$

$\mathrm{N}=$ sample size $=37$ observations

$\mathrm{K}=$ number of independent variables $=2$

So, degrees of freedom, $\mathrm{df}=37-2-1=34$

Hypothesis testing

$\mathrm{H}_{0}: \beta_{\mathrm{j}}=0$ (no linear relationship)

$\mathrm{H}_{1}: \beta_{\mathrm{j}} \neq 0$ (linear relationship does exist between $\mathrm{X}_{\mathrm{j}}$ and $\mathrm{Y}$ )

Hypotheses

$H_{0}: \beta_{1}=\beta_{2}=\beta_{3}=\beta_{4}=0$ (no linear relationship exists between CSR score, firm size, and profitability)

$\mathrm{H}_{1}: \beta_{\mathrm{i}} \neq 0$ (linear relationship exists between CSR score, firm size, and profitability)

df $=34$;

$\alpha=$ significance level $=0.05$;

$\mathrm{t}_{\alpha / 2}=\mathrm{t}_{0.025}=1.69$ from the table.

T-statistic $=$ Estimated coefficient / Estimated Standard Error of the Coefficient,

From the table T-statistics for the company size is 3.30 at $5 \%$ level of significance, it is more than 1.96 so we reject the null hypotheses, we accept the alternative hypotheses that there is sufficient evidence that firm size affects the CSR scores of companies.

For the 2nd variable, profitability, t-statistic from our report is 0.49 which is smaller than the critical value of 1.96 at $5 \%$ level of significance, so we accept the null hypotheses as there is insufficient evidence that profitability affects the CSR scores of companies.

Table 1-4:- Correlation Matrix.

\begin{tabular}{|l|l|l|l|}
\hline & Company Size & Profitability & CSR/ESG Score \\
\hline Company Size & 1 & & \\
\hline Profitability & 0.501045685 & 1 & \\
\hline CSR/ESG Score & 0.574004795 & 0.347074054 & 1 \\
\hline
\end{tabular}


Interpretation of the Regression analysis and descriptive statistical analysis for our project:

1. From our t-test we can conclude that only one independent variables, that is firm size is statistically significant for our regression analysis of individual $\mathrm{X}$-variables significance.

2. The result of $F$ test suggests that the overall model is significant.

3. From correlation we can say that firm size shows the highest correlation with the CSR scores, and profitability shows lower correlation than firm size with the CSR scores.

Part 2: Canadian Companies:

For Our data set the Regression Equation is:

$\mathrm{Y}(\mathrm{CSR})=\mathrm{b0}+\mathrm{b} 1($ firm age $)+\mathrm{b} 2($ firm size $)+\mathrm{b3}$ (Leverage) $+\mathbf{b 4}$ (Profitability)

CSR score $=71.2+0.05($ firm age $)+1.09 \mathrm{E}-05($ firm size $)+0.41$ (profitability) -0.70 (Leverage)

Table 1-5:- T-Test results.

\begin{tabular}{|l|l|l|l|l|}
\hline & Coefficients & Standard Error & t stat & p-value \\
\hline Intercept & 71.2072197 & 3.792786378 & 18.77438183 & $5.513 \mathrm{E}-32$ \\
\hline Firm age & 0.0546971 & 0.038674133 & 1.414307109 & 0.1609243 \\
\hline First size & $1.0917 \mathrm{E}-05$ & $1.53883 \mathrm{E}-05$ & 0.709450746 & 0.4799864 \\
\hline Profitability & 0.41690448 & 0.198593113 & 2.099289714 & 0.0387572 \\
\hline Leverage & -0.70694396 & 0.415281262 & -1.7023257 & 0.092349 \\
\hline
\end{tabular}

Co-efficient of multiple determinations:

The R-squared of the regression is the fraction of the variation of the dependent variable that is accounted for (or predicted by) the independent variables.

$\mathrm{R}^{2}$ reports the proportion of total variation in Y (CSR) explained by all X (Firm age, size, leverage and Profitability) variables taken together.

Table 1-6:- Regression Statistics.

\begin{tabular}{|l|l|}
\hline Regression Statistics \\
\hline Multiple R & 0.37339168 \\
\hline R Square & 0.13942135 \\
\hline Adjusted R Square & 0.09892353 \\
\hline Standard Error & 18.1258808 \\
\hline Observations & 90 \\
\hline
\end{tabular}

From the summary output of regression statistics for our dataset obtained from MS-Excel we have $\mathbf{r}^{2}=0.13$

$$
\mathrm{r}^{2}=\frac{\mathrm{SSR}}{\mathrm{SST}}=\frac{4524.34}{27926.54}=0.13
$$

Table 1-7:- Anova Analysis Results.

\begin{tabular}{|l|l|l|l|l|l|}
\hline ANOVA & df & SS & MS & F & Significance F \\
\hline & 4 & 4524.346636 & 1131.086659 & 3.4426878 & 0.011723155 \\
\hline Regression & 85 & 27926.54225 & 328.5475559 & & \\
\hline Residual & 89 & 32450.88889 & & & \\
\hline Total & \multicolumn{6}{|l}{} & & \\
\hline
\end{tabular}

So, we can infer that $13 \%$ of the variation in CSR score is explained by the variations in the firm age, firm size, leverage and profitability.

Adjusted $\mathrm{r}^{2}=0.098=0.10$

Ten per cent of the variation in CSR scores is explained by the variation in firm size, firm age, leverage and profitability, taking into account the sample size (90) and number of independent variables (4). 
Now we have to check if the Model is significant

To check we conduct the F-test:

1. F Test is conducted for checking the Overall Significance of the Model

2. F-test Shows if there is a linear relationship between all of the $\mathrm{X}$ variables considered together and $\mathrm{Y}$

\section{Hypotheses:}

$\mathrm{H}_{0}: \beta_{1}=\beta_{2}=\beta_{3}=0$ (No linear relationship).

$\mathrm{H}_{1}$ : at least one $\beta \mathrm{i} \neq 0$ (at least one independent variable affects CSR scores for companies)

F-test for overall significance:

$\mathrm{F}=3.44$ (from the regression analysis output of our data set from Ms-Excel)

Where:

F has $\quad$ (numerator) $=\mathrm{k}$ and

$($ Denominator $)=(\mathrm{n}-\mathrm{k}-1)$ degrees of freedom

Degrees of freedom $=4 \& 85$

$$
\mathrm{F}=\frac{\mathrm{MSR}}{\mathrm{MSE}}=\frac{1131.0866}{328.54}=3.44
$$

$\mathrm{P}$-value for the F-test $=0.0011723$

$\mathrm{df}_{1}=4, \mathrm{df}_{2}=85 ; \mathrm{F} \alpha=2.47$ from the table for $\alpha=0.05$ (for $95 \%$ confidence interval)

From our calculations, $\mathrm{F}$ value is 3.37 and from our analysis report $\mathrm{F}$ value is 3.44 which is larger than $\mathrm{F} \alpha=2.47$; so lies in the rejection region, so we reject the null hypothesis. The $\mathrm{P}$ value tells us how confident we can be that each individual variable has some correlation with the dependent variable, which is the important thing.

So, considering the $\mathrm{P}$-value, at $\alpha=0.05$ ( $\mathrm{p}$-value < .05), reject $\mathrm{H}_{0}$

\section{Conclusion:-}

There is evidence that at least one independent variable (Firm age, firm size, profitability and leverage) affects the CSR SCORE of companies. So, the Model is over all significant.

\section{To check if individual variables are significant: $t$-test:}

We conduct the T-test to check if each of the independent variables (i.e. Firm age, Firm size, Profitability and leverage) are significant individually are not.

1. Use $t$ tests of individual variable slopes

2. Shows if there is a linear relationship between the variable $\mathrm{X}_{\mathrm{j}}$ and $\mathrm{Y}$.

\section{Test Statistic:}

$\mathrm{t}=\mathrm{b}_{\mathrm{j}}-0$

$\mathrm{S}_{\mathrm{bj}}$

$(\mathrm{df}=\mathrm{n}-\mathrm{k}-1)$

Test Statistic

$(\mathrm{df}=\mathrm{n}-\mathrm{k}-1)=$

$\mathrm{N}=$ sample size $=30$ observations

$\mathrm{K}=$ number of independent variables $=4$

So degrees of freedom, $\mathrm{df}=90-4-1=85$

Hypothesis testing

$\mathrm{H}_{0}: \beta_{\mathrm{j}}=0$ (no linear relationship)

$\mathrm{H}_{\mathrm{i}}: \beta_{\mathrm{j}} \neq 0$ (linear relationship does exist between $\mathrm{X}_{\mathrm{j}}$ and $\mathrm{Y}$ )

\section{Hypotheses}

$\mathrm{H}_{0}: \beta_{1}=\beta_{2}=\beta_{3}=\beta_{4}=0$ (no linear relationship exists between CSR score, firm size, profitability, and leverage)

$\mathrm{H}_{1}: \beta_{\mathrm{i}} \neq 0$ (linear relationship exists between CSR score, firm size, profitability, and leverage)

df $=85$;

$\alpha=$ significance level $=0.05$;

$\mathrm{t}_{\alpha / 2}=\mathrm{t}_{0.025}=1.66$ from the table.

t-statistic $=$ Estimated coefficient $/$ Estimated Standard Error of the Coefficient, 
From the table T-statistics for firm age is 1.41 at $5 \%$ level of significance, which is less than 1.66 so we do not reject the null hypotheses, we accept the null hypotheses that there is insufficient evidence that firm age affects the CSR scores of Companies.

For the 2nd variable, firm size, $t$-statistic from our report is 0.709 which is smaller than the critical value of $t$ at $5 \%$ level of significance, so we accept the null hypotheses as there is insufficient evidence that firm size affects the CSR scores of Companies.

For the 3rd variable profitability, the T-statistic from our analysis report is: 2.099 for $5 \%$ level of significance, it is more than 1.66 so we reject the null hypotheses, we accept the alternative hypotheses that there is sufficient evidence that profitability affects the CSR scores of companies.

For the 4th variable, leverage, $t$-statistic from our report is -1.70 which is smaller than the critical value of $t$ at $5 \%$ level of significance, so we accept the null hypotheses as there is insufficient evidence that leverage affects the CSR scores of Companies.

\section{Results of the Regression analysis and descriptive statistical analysis in this study:}

1. From our t-test we can conclude that only one independent variables, that is profitability is statistically significant for our regression analysis of individual $\mathrm{X}$-variables significance.

2. From the F-test the overall model is significant.

3. From correlation we can say that Profitability shows the highest correlation with the CSR scores, and other independent variables show lower correlation with the CSR scores.

\section{Conclusion:-}

The findings from this studysupports past research findings that a firm's involvementin CSR activities is influenced by its location and profitability. It further confirms that the level of a company's involvement in CSR activities varies from country to country (Fisher, 2017) and from region to region (Sisaye, 2016) through itsempirical analysis conducted on 37 publicly traded companies headquartered in Saskatchewan province in the first stage and on 90 companies all over Canada in the second stage. In addition to the above outcomes, the results also showed that "company size" has significant and positiveinfluence on a firm in its involvement in CSR activities within the Saskatchewan province. But, when90 companies headquartered in other provinces also were tested through regression analysis, the results varied and company size lost its significance in the model and only profitability as the independent variable showed to exhibit positive influence on a firm's involvement in CSR activity. This probably could be due to cultural differences, tax regulations, economic, social and political factors all of which needs further exploration. Also, the firms age and leverage were found to be insignificant and do not seem to contribute towards a firm's involvement in CSR activities in the context of companies in Canada considered in the analysis in this research.

Also, in a bid to find out the influence of company reputation on CSR activity, 50 companies were studied with company reputation as independent variable, but the model had no significance indicating that company reputation does not influence its involvement in CSR activities. This could be due to the method adopted to measure company reputation.

Hence it can be concluded that firms with more profits indulge in CSR activities and geographical location does exert some influence on a firm's involvement in CSR activities.

\section{Bibliography:-}

1. Abbott, W.F. and Monsen, R. (1979) On the Measurement of Corporate Social Responsibility: Self-Reported Disclosure as Method of Measuring of Corporate Social Involvement, Academy of Management Review, 22, 501-515.

2. Adams, C. A., Hill, W. Y., \& Roberts, C. B. (1998). Corporate social reporting practices in western Europe: Legitimating corporate behavior? British Accounting Review, 30(1), 1-12.

3. Akin, A., \& Yilmaz, I. (2016). Drivers of Corporate Social Responsibility Disclosures: Evidence from the Turkish Banking Sector. Procedia Economics and Finance, 38, 2-7.

4. Alexander, G. J. and R. A. Buchholz: 1978, 'Corporate Social Performance and Stock Market Performance,' 
Academy of Management Journal 21, 479-486.

5. Alturki, K.H., 2014. Voluntary Disclosure by Saudi Companies. Research Journal of Finance and Accounting, 5(20): 77-95

6. Badulescu, A., Badulescu, D., Saveanu, T. and Hatos, R. (2018). The Relationship between Firm Size and Age and Its Social Responsibility Actions-Focus on a Developing Country (Romania). Sustainability, 10(3), p.805.

7. Bertazzi, P. (n.d.). The GRI Guidelines to report sustainability. [online] Globalreporting.org. Available at: https://www.globalreporting.org/SiteCollectionDocuments/The-GRI-Guidelines-to-report-sustainability.pdf

8. BerthoinAntal, Ariane; Dierkes, Meinolf; MacMillan, Keith; Marz, Lutz (2002) :

9. Corporate social reporting revisited, WZB Discussion Paper, No. FS II 02-105, Wissenschaftszentrum Berlin fürSozialforschung (WZB), Berlin

10. Carroll, A. B. (2016). Carroll's pyramid of CSR: taking another look. International Journal of Corporate Social Responsibility, 1(1). doi: 10.1186/s40991-016-0004-6

11. Dierkes, M., \& Preston, L. E. (1977). Corporate social accounting and reporting for the physical environment: A critical review and implementation proposal. Accounting, Organizations and Society, 2(1), 3-22.

12. Dowling, J. and Pfeffer, J. (1975). Organizational Legitimacy: Social Values and Organizational Behavior. The Pacific Sociological Review, 18(1), pp.122-136.

13. European Commission: Choose your language: Choisirune langue: Wählen Sie eineSprache. (n.d.). Retrieved from http://ec.europa.eu/.

14. Fisher, Victoria, "An International Analysis of CSR Rankings and a Country's Culture" (2017). Senior Honors Theses. 561. http://commons.emich.edu/honors/561

15. Gamerschlag, R., Möller, K. and Verbeeten, F. (2011). Determinants of voluntary CSR disclosure: empirical evidence from Germany. Review of Managerial Science, 5(2-3), pp.233-262 [Cross referencing]

16. Gleeson-White JL, 2011, Double Entry: How the merchants of Venice shaped the modern world - and how their invention could make or break the planet, First, Allen \& Unwin, Sydney, Australia, http://www.allenandunwin.com/

17. Hackston, D., \& Milne, M. J. (1996). Some determinants of social and environmental disclosures in New Zealand companies. Accounting, Auditing \& Accountability Journal, 9(1), 77-108

18. Horúcková, M. and Baudassé, T. (2017). Content Analysis Applied To Social And Environmental Reporting. Acta academicakarviniensia, 17(4), pp.32-45.

19. Hossain, M., 2008. The extent of disclosure in annual reports of banking companies: The case of India. European Journal of Scientific Research, 23(4): 659-680

20. Jackson, Leonard A. and Hua, Nan (2009) "Corporate Social Responsibility and Financial Performance: A Snapshot from the Lodging and Gaming Industries," Journal of Hospitality Financial Management: Vol. 17: Iss. 1 Article 4, pp. 63-78

21. Kansal, M.; Joshi, M.; Batra, G.S. Determinants of corporate social responsibility disclosures: Evidence from India. Advances in Accounting, vol. 30, no. 1, 2014, pp. 217-229.

22. Marom, I. Y. (2006) "Towards a unified theory of the CSPCFP link," Journal of Business Ethics, 67, 191-200.

23. McWilliams, A., and Siegel, D. (2001) Corporate social responsibility: A theory of the firm perspective. Academy of management review, 26(1), 117-127.

24. Mousa et al., G. (2015). Legitimacy Theory and Environmental Practices: Short

25. Notes. International Journal of Business and Statistical Analysis, 2(1), pp.41-53

26. Murtala Zakari. The Relationship Between Corporate Social Responsibility and Profitability: The Case of Dangote Cement Plc. Journal of Finance and Accounting. Vol. 5, No. 4, 2017, pp. 171-176.

27. Patten, D. (1991). Exposure Legitimacy and Social Disclosure. Journal of Accounting and Public Policy, 10, 297-308.

28. Purushotahman, M., Phil, H., \& Ross, T. (2000). Determinants of corporate social reporting practices of listed Singapore companies. An Accounting Review, 12(2), 101-103

29. Rabie, M. (2013). Saving capitalism and democracy. New York, NY: Routledge.

30. Rodriguez-Fernandez, M. (2016). Social responsibility and financial performance: The role of good corporate governance. BRQ Business Research Quarterly, 19(2), pp.137-151.

31. Roberts, R.W., (1992). Determinants of corporate social responsibility disclosure: An application of stakeholder theory. Accounting, Organisations and Society, 17(6), 595-612 [cross reference]

32. Schreck, P. and Raithel, S. (2015). Corporate Social Performance, Firm Size, and Organizational Visibility: Distinct and Joint Effects on Voluntary Sustainability Reporting. Business \& Society, 57(4), pp.742-778.

33. Sisaye, S., 2016. Ecology, Sustainability Development And Accounting Reporting Systems: A Comparative Approach. [online] Decisionsciences.org. 
34. Smith, N. (2013). When It Comes to CSR, Size Matters. [online] Forbes.com. Available at: https://www.forbes.com/sites/insead/2013/08/14/when-it-comes-to-csr-size-matters/.

35. Subramanian, S. (2018). Stewardship Theory of Corporate Governance and Value System: The Case of a Family-owned Business Group in India. Indian Journal of Corporate Governance, 11(1), pp.88-102.

36. Thomas, L. C. (2014, June 27). The Status of CSR in Corporate America: A Content Analysis of the Organizations with the Top-Performing CSR Programs Within the Fortune 500. Retrieved from https://scholarsarchive.byu.edu/etd/4185/.

37. Van der Laan, Sandra (2009), The Role of Theory in Explaining Motivation for Corporate Social Disclosures: Voluntary Disclosures vs 'Solicited' Disclosures, Australasian Accounting, Business and Finance Journal, 3(4).

38. Waluyo, W. (2017). Firm Size, Firm Age, and Firm Growth on Corporate Social Responsibility in Indonesia: The Case of Real Estate Companies. European Research Studies Journal, XX (Issue 4A), 360-369.

39. Wilburn, K. and Wilburn, R. (2013). Using Global Reporting Initiative indicators for CSR programs. Journal of Global Responsibility, 4(1), pp.62-75.

\section{Appendix:-}

Assumptions of Multiple regression:

\section{Part 1:}

Linearity test between Dependent and Independent Variables: The scatter plots indicates that the relationship between the dependent and independent variable can be modelled by a straight line suggesting that the relationship between these variables is linear.
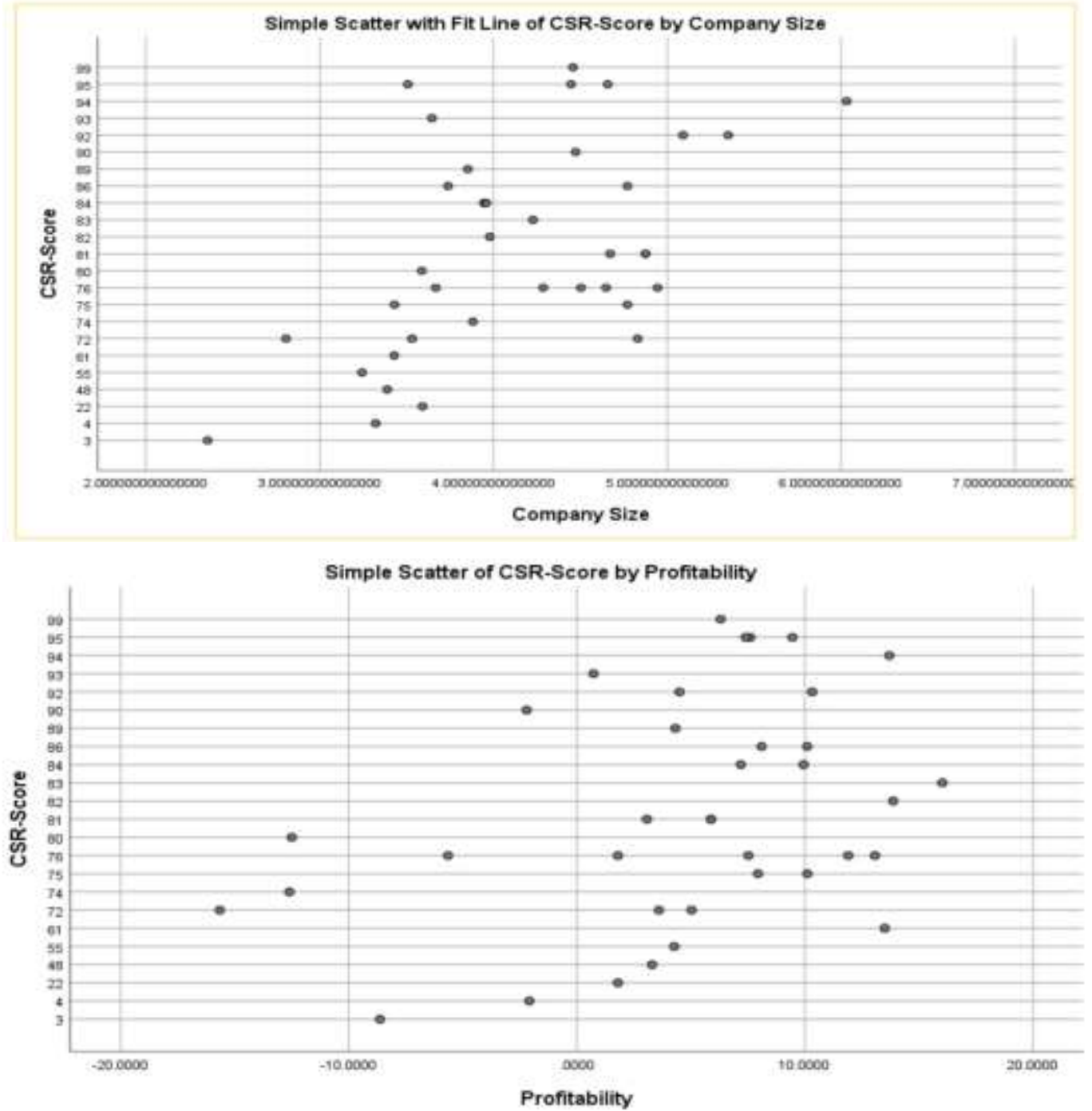
Multicollinearity test: There is no multicollinearity in the data sample; predictors are not strongly correlated. This assumption is met.

\section{Correlations}

\begin{tabular}{|c|c|c|c|c|}
\hline & & CSR-Score & Profitability & $\begin{array}{c}\text { Company } \\
\text { Size }\end{array}$ \\
\hline \multirow[t]{3}{*}{ Pearson Correlation } & CSR-Score & 1.000 & .347 & .574 \\
\hline & Profitability & .347 & 1.000 & .501 \\
\hline & Company Size & .574 & .501 & 1.000 \\
\hline
\end{tabular}

VIF scores are well below 10 and tolerance scores are above 0.2

\begin{tabular}{|c|c|c|c|c|c|c|c|c|}
\hline \multirow[b]{3}{*}{ Model } & \multicolumn{8}{|c|}{ Coefficients $^{a}$} \\
\hline & & \multicolumn{2}{|c|}{ Unstandardized Coefficients } & \multirow{2}{*}{$\begin{array}{c}\text { Standardized } \\
\text { Coefficients } \\
\text { Bota }\end{array}$} & \multirow[b]{2}{*}{$\mathrm{t}$} & \multirow[b]{2}{*}{ sig } & \multicolumn{2}{|c|}{ Collinearity Statistics } \\
\hline & & B & std. Errot & & & & Tolerante & MF \\
\hline \multirow[t]{3}{*}{1} & (Constant) & 7.633 & 18.322 & & 395 & .695 & & \\
\hline & Profitability & .235 & .478 & .079 & 491 & 627 & 749 & 1.335 \\
\hline & Company Size & 16.059 & 4.861 & .534 & 3.304 & .002 & 749 & 1.335 \\
\hline
\end{tabular}

a. Dependent Variable: CSR-Score

The values of the residuals are independent:

since we us cross sectional data, this test is irrelevant (Durbin-Watson); Yet, since the value is close to 2 which so this assumption is met.

Model Summary ${ }^{\text {b }}$

\begin{tabular}{l|l|r|r|r|r} 
Model & $R$ & R Square & \multicolumn{1}{c}{$\begin{array}{c}\text { Adjusted R } \\
\text { Square }\end{array}$} & $\begin{array}{c}\text { Std. Error of } \\
\text { the Estimate }\end{array}$ & \multicolumn{1}{c}{$\begin{array}{l}\text { Durbin- } \\
\text { Watson }\end{array}$} \\
\hline 1 & $.578^{\mathrm{a}}$ & .334 & .295 & 19.034 & 1.823 \\
\hline
\end{tabular}

a. Predictors: (Constant), Company Size, Profitability

b. Dependent Variable: CSR-Score

The variance of the residuals is constant:

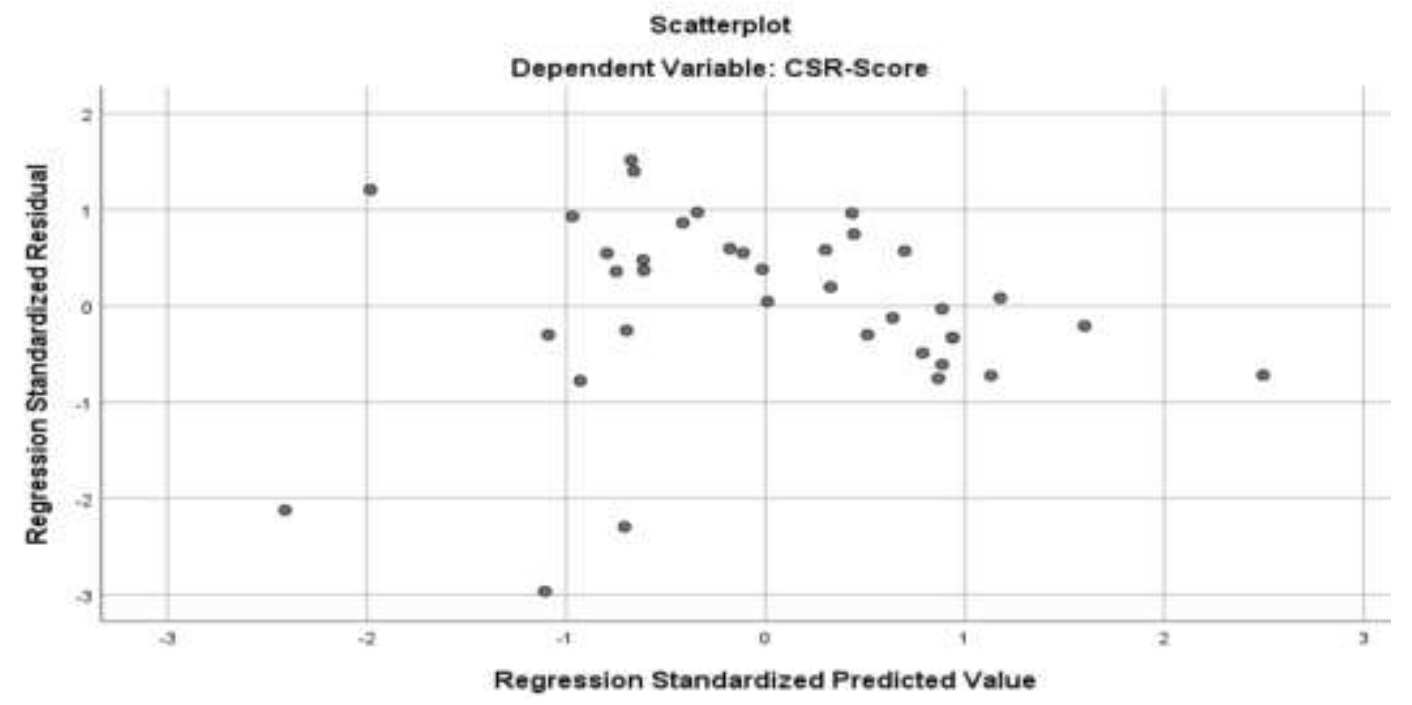


The values of the residuals are normally distributed :

Normal P.P Plot of Regression Standardized Residual

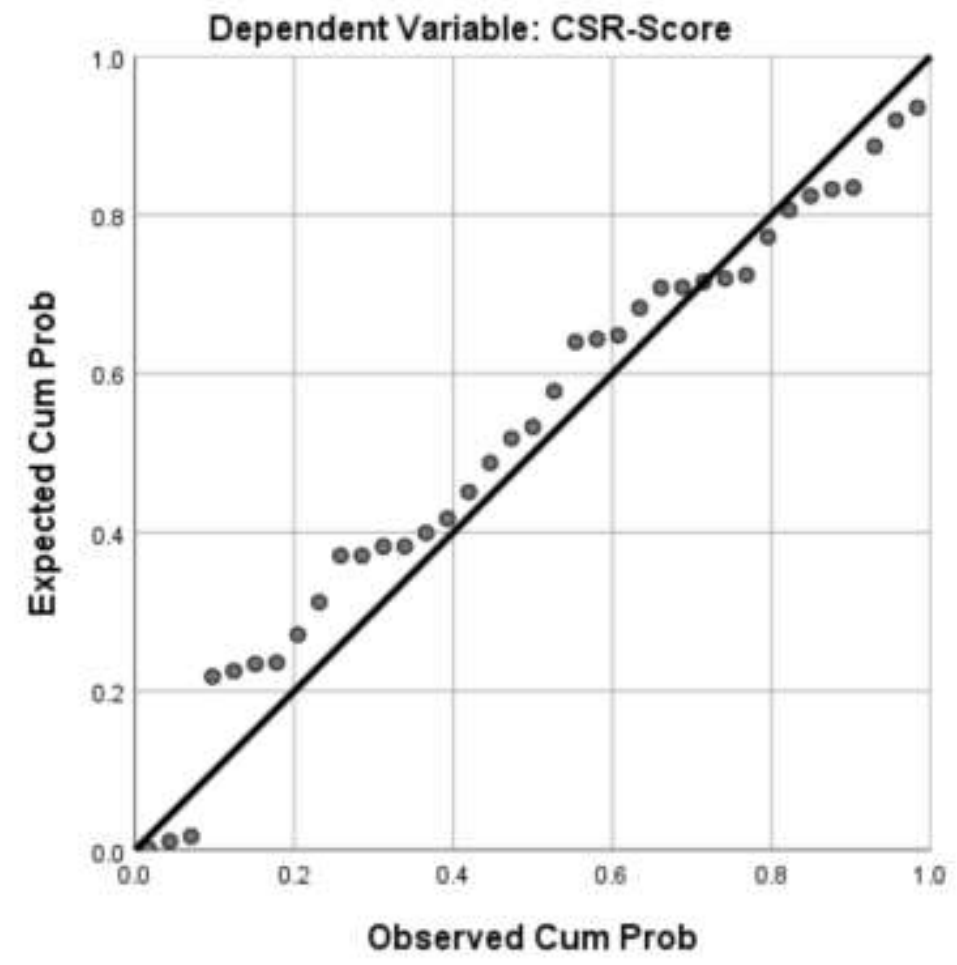

\section{Conclusion:-}

All the assumptions are met, hence the data is valid for regression analysis.

\section{Part 2:}

To test the relationship between Dependent and Independent Variables

Dependent Variable $=$ CSR score

Independent Variable = Firm Age; Firm size; Profitability; Leverage

\section{Linearity test:}

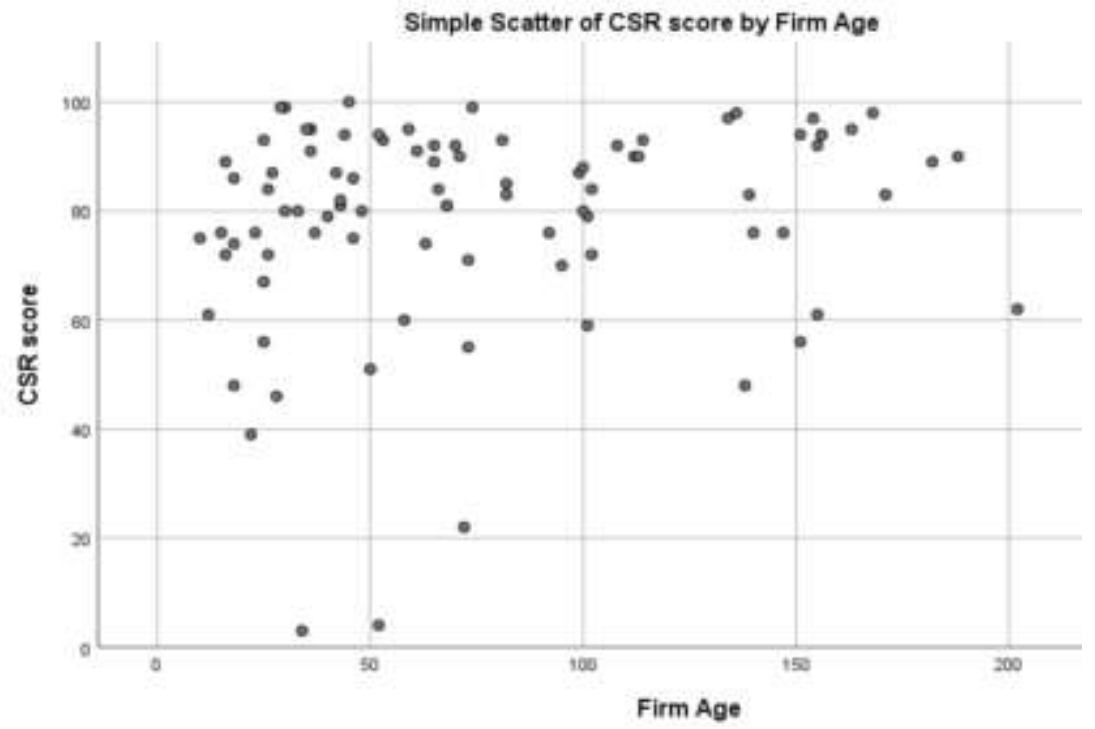




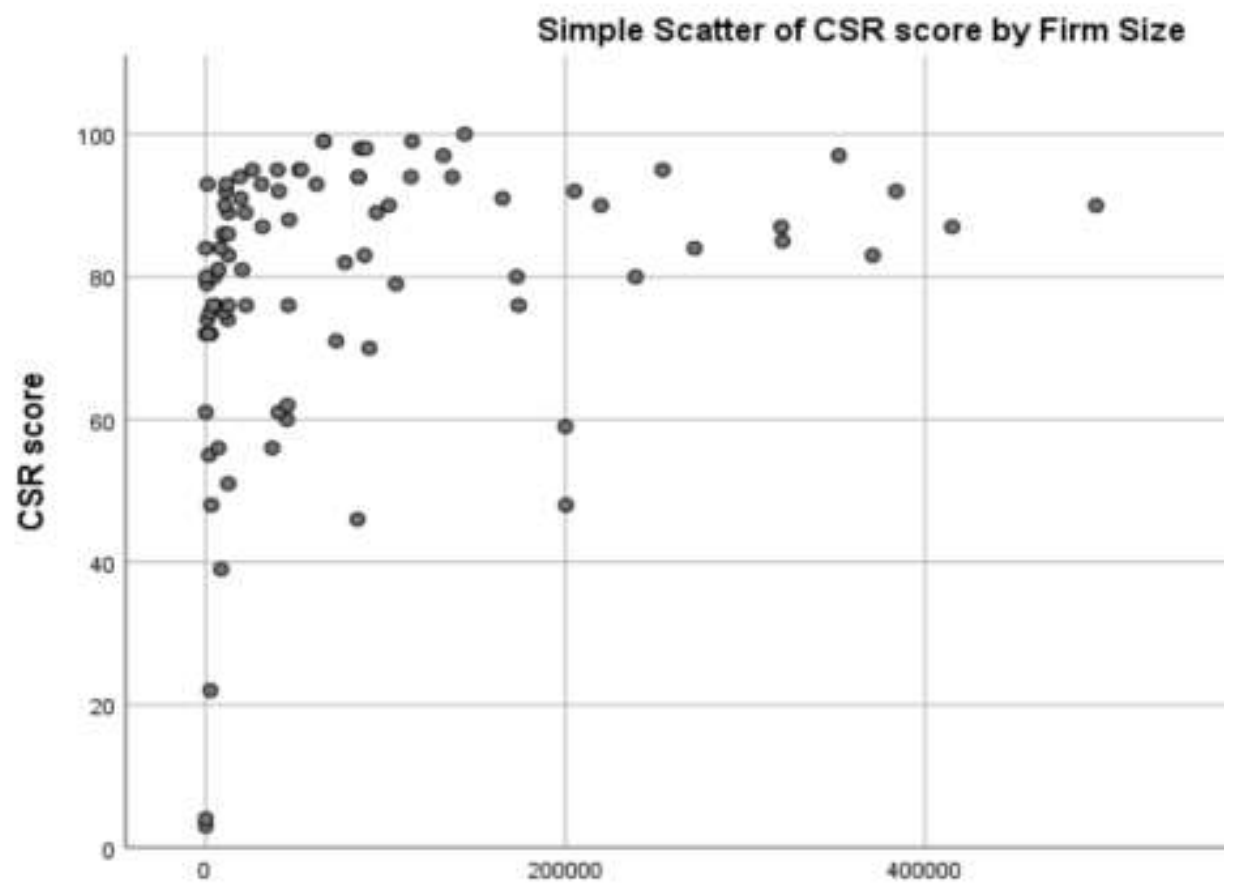

Firm Size

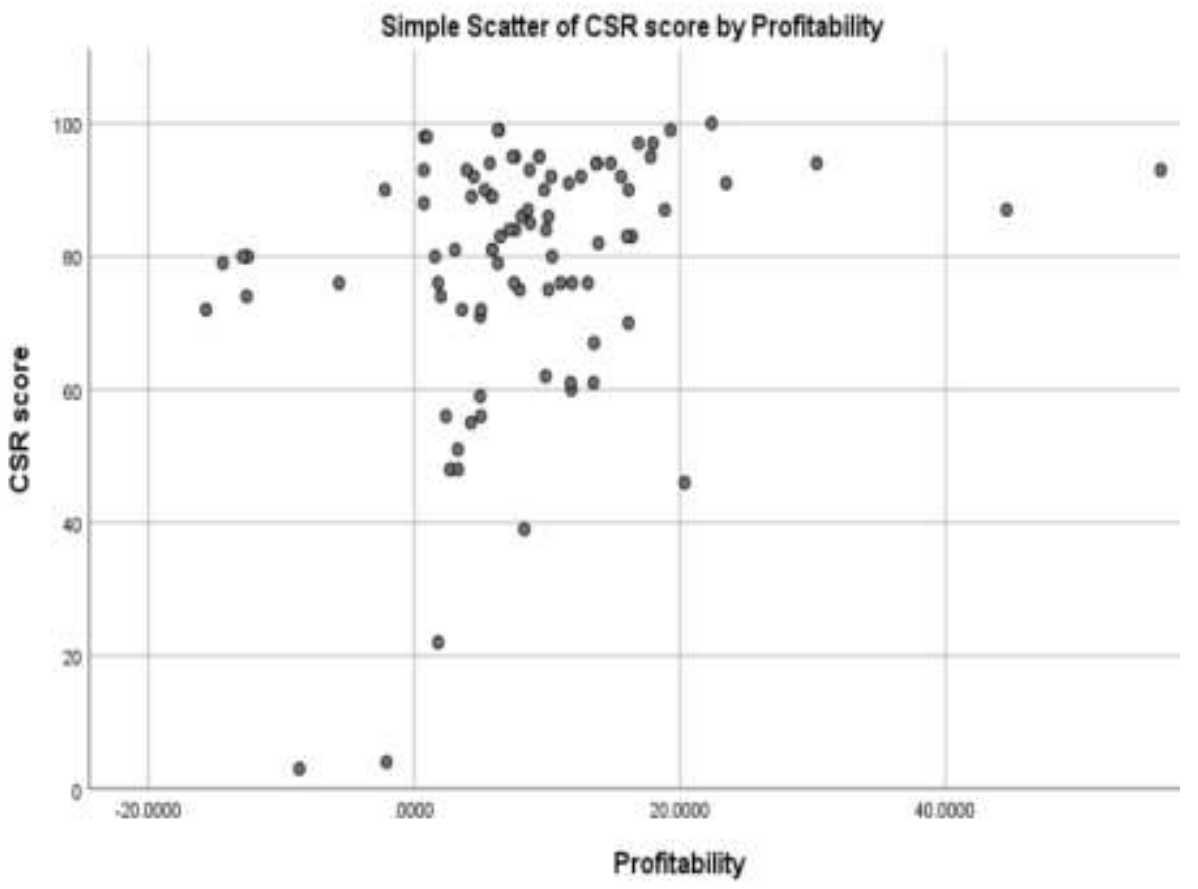




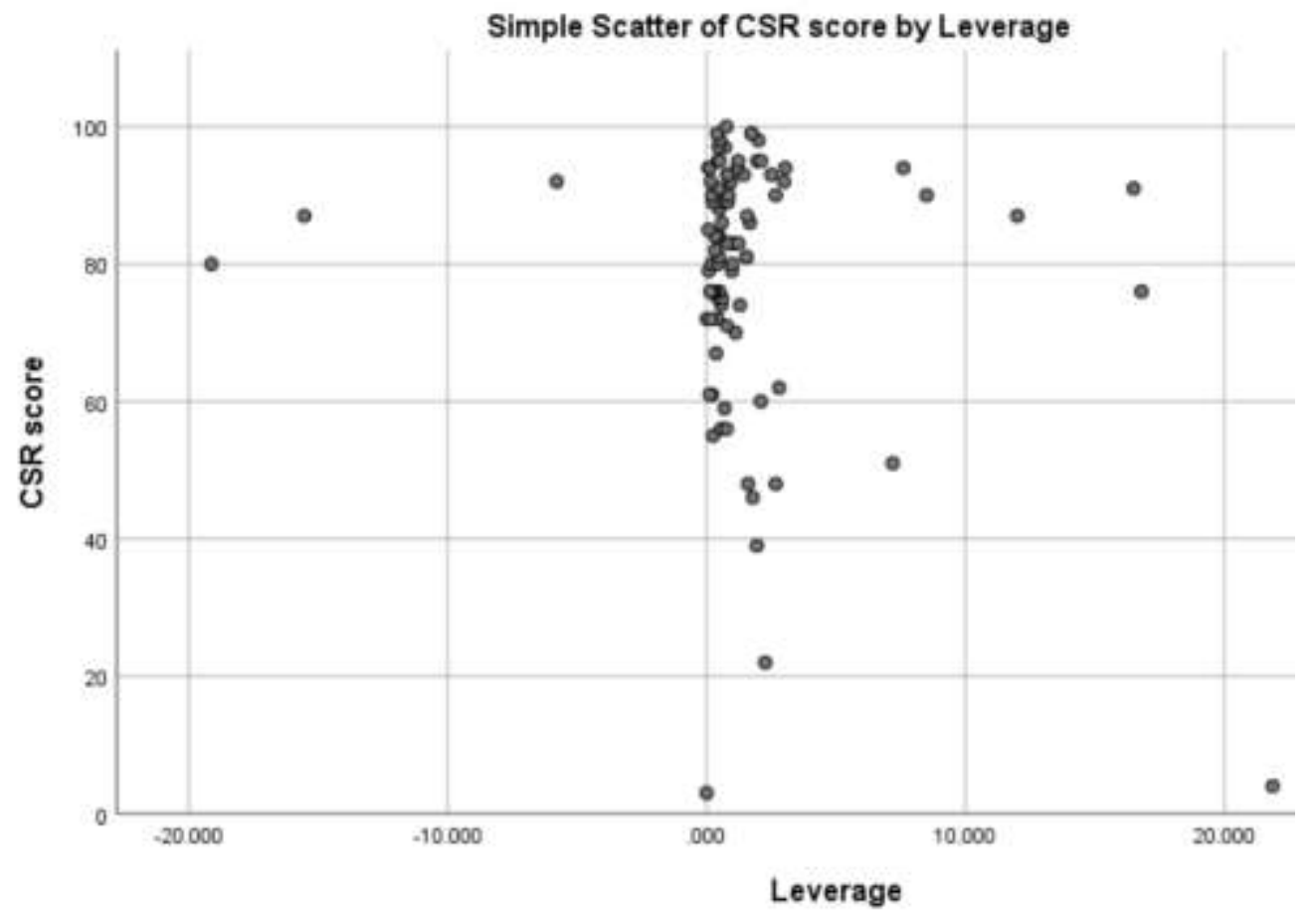

\section{Correlation test:}

\begin{tabular}{|c|c|c|c|c|c|c|}
\hline \multicolumn{7}{|c|}{ Correlations } \\
\hline & & CSR score & Firm Age & Firm Size & Profitability & Leverage \\
\hline \multirow[t]{5}{*}{ Pearson Correlation } & CSR score & 1.000 & .173 & .177 & .292 & -.201 \\
\hline & Firm Age & .173 & 1.000 & .123 & .117 & .041 \\
\hline & Firm Size & .177 & .123 & 1.000 & .335 & .044 \\
\hline & Profitability & .292 & .117 & .335 & 1.000 & -.133 \\
\hline & Leverage & -.201 & .041 & -.044 & -.133 & 1.000 \\
\hline
\end{tabular}

There is no strong correlation between independent variables.

From the co-relation matrix, it can be seen that no two variables have any strong correlation between them. Amongst all variable, only profitability has a stronger correlation with CSR score. Firms' leverage has negative co-relation.

\section{Collinearity test:}

\begin{tabular}{|c|c|c|c|c|c|c|c|c|}
\hline \multicolumn{9}{|c|}{ Coefficients $^{a}$} \\
\hline \multirow[b]{2}{*}{ Model } & & \multicolumn{2}{|c|}{ Unstandardized Coefficients } & \multirow{2}{*}{$\begin{array}{l}\text { Standardized } \\
\text { Coefficients } \\
\text { Beta }\end{array}$} & \multirow[b]{2}{*}{1} & \multirow[b]{2}{*}{ Sig. } & \multicolumn{2}{|c|}{ Collinearity Statistics } \\
\hline & & B & Std. Error & & & & Tolerance & MF \\
\hline \multirow[t]{5}{*}{1} & (Constant) & 71.207 & 3.793 & & 18.774 & .000 & & \\
\hline & Firm Age & .055 & .039 & .144 & 1.414 & .161 & 975 & 1.025 \\
\hline & Firm Size & $1.092 E-5$ & .000 & .076 & .709 & 480 & 881 & 1.135 \\
\hline & Profitability & .417 & .199 & .227 & 2.099 & .039 & .867 & 1.153 \\
\hline & Leverage & -.707 & 415 & -173 & -1.702 & .092 & 979 & 1.021 \\
\hline
\end{tabular}

a. Dependent Variable: CSR score

VIF is below 10; Tolerance scores are above 0.2 ; hence this assumption is met. 
Values of the residuals are independent:

Since we are using cross-sectional data we assume that this assumption is met.

The values of the residuals are normally distributed:

our data points touch the line indicating that this assumpiton is met
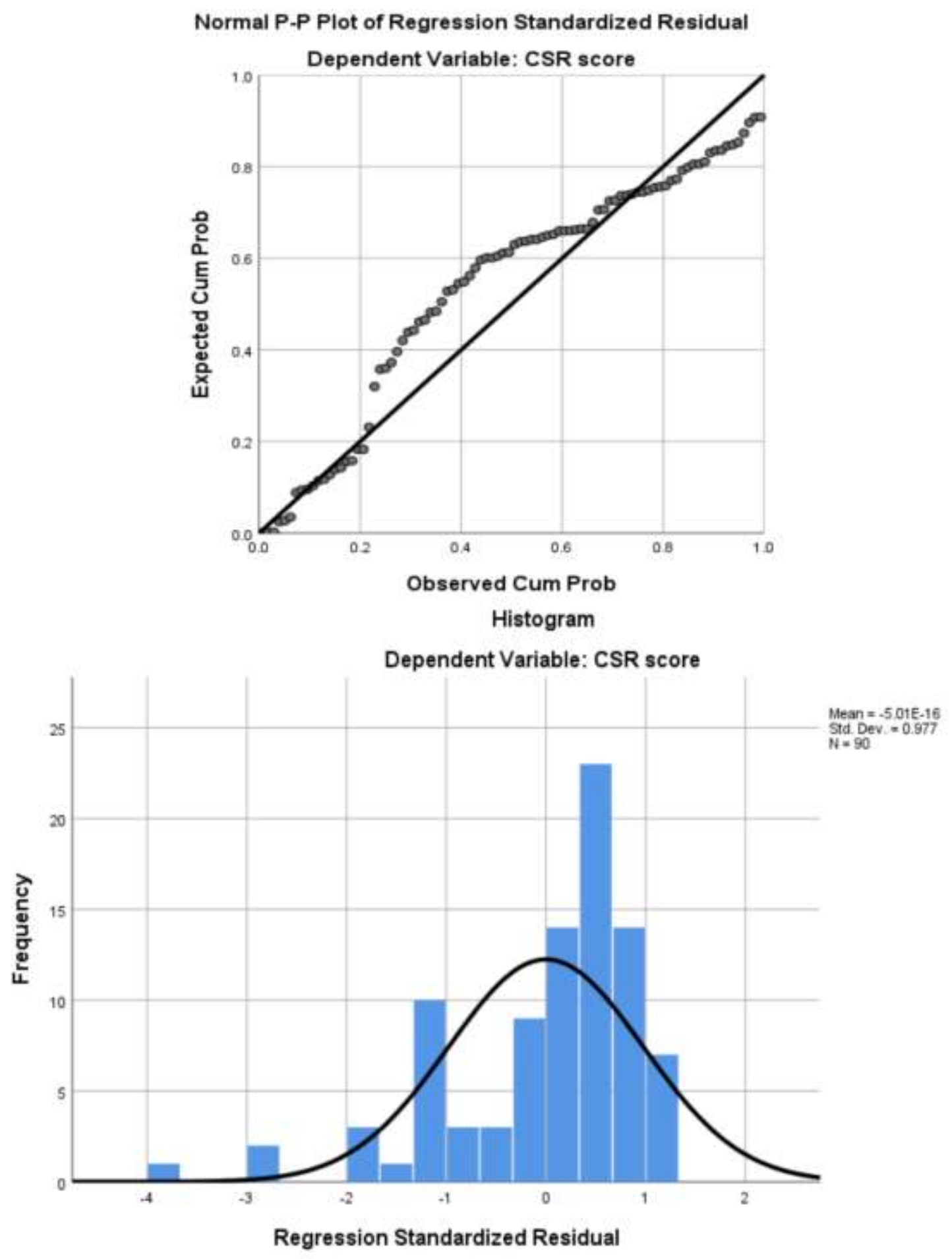
Variance of residuals is constant:

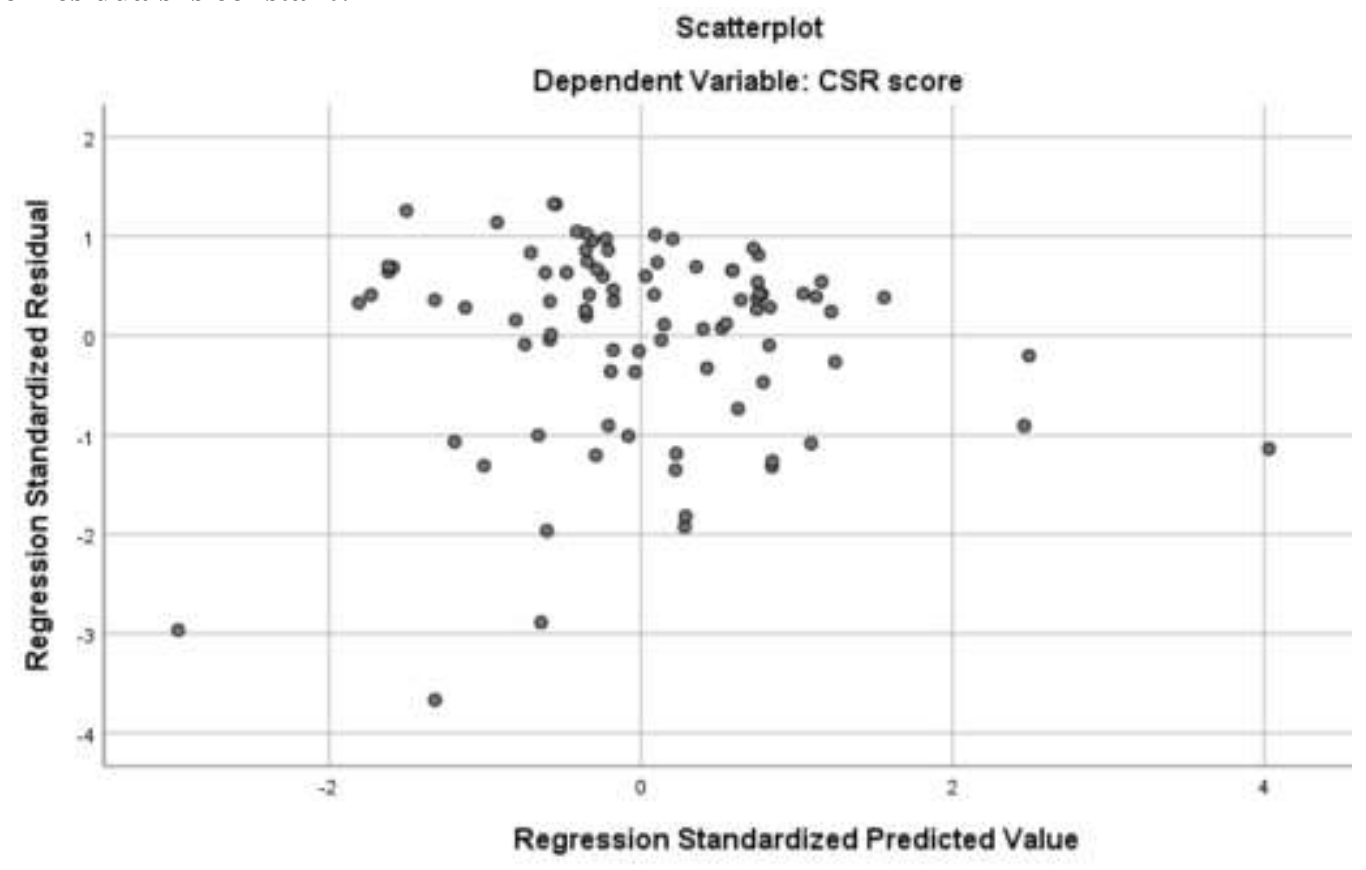

This is test is met; since the points are all centered around the line of zero.

There are no influential cases biasing our model:

Since we do not have any value over 1 there are no significant outliers and this test is met.

\begin{tabular}{|l|l|l|l|l|l|}
\hline .14457 & $\mathbf{. 0 3 3 1 4}$ & .00013 & .00005 & .00520 & .01221 \\
.70196 & .22765 & .00015 & .00042 & .00416 & .00276 \\
.03185 & .00218 & .00001 & .00104 & .00156 & .00400 \\
.02318 & .00033 & .00680 & .00016 & .06618 & .00465 \\
.03426 & .00005 & .00037 & .00093 & .00282 & .00332 \\
.03142 & .00059 & .06715 & .00252 & .00060 & .00432 \\
.01115 & .00210 & .00694 & .00204 & .00243 & .00402 \\
.00853 & .00001 & .00724 & .15266 & .00174 & .00255 \\
.00530 & .00266 & .00050 & .00490 & .00244 & .00211 \\
.01808 & .00000 & .00021 & .00166 & .00560 & .00829 \\
.00552 & .00009 & .00021 & .00104 & .00212 & .01247 \\
.00765 & .00311 & .00006 & .00450 & .00803 & .00338 \\
.00362 & .00130 & .00008 & .00136 & .00193 & .00763 \\
.01710 & $\mathbf{. 0 0 1 8 4}$ & .00089 & .00204 & .00258 & .00785 \\
.00740 & .00087 & .00009 & .00127 & .00169 & .00649 \\
\hline
\end{tabular}

CSR as dependent, Company reputation, company size and company age as independent variables: Model Insignificant:

ANOVA

\begin{tabular}{l|rccc|c}
\hline & $d f$ & \multicolumn{1}{c}{ SS } & MS & $F$ & Significance $F$ \\
\hline Regression & 3 & 686.5862 & 228.8621 & 0.859552402 & 0.468842378 \\
\hline Residual & 46 & 12247.83 & 266.2573 & & \\
\hline Total & 49 & 12934.42 & & & \\
\hline
\end{tabular}




\begin{tabular}{|lrrrc|}
\hline & \multicolumn{1}{c|}{ Coefficients } & Standard Error & \multicolumn{1}{c|}{ Stat } & P-value \\
\hline Intercept & 63.97631612 & 13.25177675 & 4.827754 & $1.56316 \mathrm{E}-05$ \\
Company Reputatior & 0.169735641 & 0.189234492 & 0.896959 & 0.374411108 \\
Company Size (No. o & $1.18625 \mathrm{E}-05$ & $1.56991 \mathrm{E}-05$ & 0.755619 & 0.453729882 \\
\hline Age & 0.068002852 & 0.051056594 & 1.331911 & 0.189451339 \\
\hline
\end{tabular}

CSR as dependent variable and COMPANY REPUTATION ALONE as independent variable: Model Insignificant:

\begin{tabular}{|c|c|c|c|c|c|c|}
\hline \multicolumn{7}{|l|}{ ANOVA } \\
\hline & $d f$ & SS & MS & $F$ & \multicolumn{2}{|c|}{ Significance $F$} \\
\hline Regression & 1 & 86.94329 & 86.94329 & 0.324833 & \multicolumn{2}{|c|}{0.571375954} \\
\hline Residual & 48 & $12847.48 \quad 26$ & 267.6558 & & & \\
\hline \multirow[t]{2}{*}{ Total } & 49 & 12934.42 & & & & \\
\hline & & Coefficients & \multicolumn{2}{|c|}{ Standard Error } & tat & $P$-value \\
\hline \multicolumn{2}{|l|}{ Intercept } & 76.17875084 & \multicolumn{2}{|c|}{49.687037369} & 63989 & $3.54 \mathrm{E}-10$ \\
\hline \multicolumn{2}{|c|}{ Company Reputation } & 0.096460043 & \multicolumn{2}{|c|}{$0.169245723 \quad 0$} & 69941 & 0.571376 \\
\hline
\end{tabular}

